\title{
Rescuing Irrigated Desert Agriculture
}

\author{
Russell Clemings \\ The Fresno Bee, 1626 E. Street, Fresno, CA 93786
}

Irrigated desert agriculture has been practiced since the dawn of civilization in the Nile, Indus, and Tigris-Euphrates valleys. But this ancient art has been fundamentally changed in the past 150 years by a series of developments beginning with the British takeover of India in the late $1840 \mathrm{~s}$. As a result, whereas desert agriculture once accounted for only a tiny sliver of the world's farm production, today it accounts for about one-third. Ensuring that this level of production is sustained and perhaps even expanded in the face of nagging side effects like waterlogging and salinity is likely to be a major challenge in the early 21 st century. The solution may lie in the widespread adoption of modern, efficient water management techniques and equipment, of which one example is drip irrigation.

Until 1847, when British civil engineers arrived in the Punjab to extend that region's ancient and rudimentary canal system, irrigation was principally a feature of "oasis civilizations." Congregating along the banks of rivers like the Nile, these civilizations used river flows to water crops that were no more than a few dozen kilometers away, and for the most part supported only local populations, albeit sometimes quite large ones. In the Punjab, by contrast, the British ran canals great distances from the rivers that nourished them, and in time, produced sufficient yields for the Punjab to become India's primary food producing region (Michel, 1969).

The British success in the Punjab inspired imitators in other English-speaking countries, including Australia and the United States; after a number of false starts and failed projects, another milestone in modern irrigated agriculture was reached with the construction of Boulder (Hoover) Dam on the Colorado River in the 1920s. This achievement built on the British experience by adding large storage reservoirs to the river system, thus freeing the downstream irrigation works from their dependence on the run-of-the-river. Instead of timing crop production to match seasonal variations in water flows, farmers in places like the Imperial Valley of California could now grow crops when solar conditions were optimal, or when market demand was strongest. Along with improvements in transportation and refrigeration, this time-shifting is what allows us today to take for granted the ability to buy fresh lettuce in Chicago in the dead of winter, something that our grandparents would have considered quite odd.

Perhaps the greatest benefit of these advancements, however, has come in the last three decades with the advent of the Green Revolution. School children of the 1950s and 1960s were admonished to eat their vegetables because other children in places like China and India were starving. Today, by virtue of new irrigation-dependent strains of wheat and rice, famines in those and other regions are rare, and when they do occur, the cause is more likely to be political than agricultural. In the early 1950s, according to the United Nations Food and Agriculture Organization, $\approx 23 \%$ of the world's 3 billion people did not get enough to eat; by the mid-1990s, that figure had fallen to $9 \%$ of a population of more than 5 billion (Norse, 1992).

From the standpoint of popular wisdom, this explosive growth in irrigated agricultural production and the consequent reduction in hunger is one of the great unrecognized trends of the 20th century. Yet one nagging question remains: Is this bounty permanent, or will it diminish in the 21 st century? There is a good chance that it can be permanent, but only if the past century's gains from improvements in irrigation can be preserved and extended.

The importance of this task must not be underestimated. At the birth of the Nile, Indus, and Mesopotamian civilizations, the entire planet supported fewer than 100 million people, maybe far fewer. In the mid-19th century, at the dawn of modern irrigated civilization on

Received for publication 15 Sept. 1999. Accepted for publication 18 Oct. 1999. The cost of publishing this paper was defrayed in part by the payment of page charges. Under postal regulations, this paper therefore must be hereby marked advertisement solely to indicate this fact. the Indus plain, it supported $\approx 1.3$ billion. By the mid-1950s, when the Asian famines prompted the research that led to the Green Revolution, there were just under 3 billion. Now, at the end of the 20th century, with high-yielding seeds and modern, massive, irrigated agriculture in use on every continent except Antarctica, the world has more than 5.3 billion people. Current estimates now project that there will be 8.6 billion people by 2025 ; the optimists forecast that the population will stabilize a few years later, at about 10 billion (Horiuchi, 1992).

Some experts foresee a Malthusian crisis in the decades to come. "Soil erosion, air pollution, soil compaction, aquifer depletion, the loss of soil organic matter and the waterlogging and salting of irrigated land are all slowing the rise in food output," writes Lester R. Brown, president of the Worldwatch Institute. "At present there is nothing in sight to reverse the worldwide decline in grain output per person. The bottom line is that the world's farmers can no longer be counted on to feed the projected additions to our numbers" (Brown, 1994). Malthus, of course, was wrong in his predictions of an 18th century global population crash, and these latter-day experts may be proved wrong as well. But Malthus erred mainly in failing to foresee how industrialization could stretch scarce resources to accommodate a burgeoning global population. Whether agriculture in the 21 st century will be able to perform a similar magic act-building upon the technological advances of the last century and a half without losing ground to side effects like salinity-remains an open question.

Still, there is good reason to be hopeful. At present, agriculture worldwide is not even close to making full use of the technological innovations that have brought it to this point. The recent history of agriculture is characterized by a steady rise in average yields brought about through increasingly heavier application and more efficient management of the inputs of production. Today, the popular image of the farmer as a barely educated bumpkin is laughably out-of-date, at least in the developed world. Farming these days requires degrees in agriculture, familiarity with personal computers, and a good working knowledge of chemistry, botany, and economics. Producing crops is now much like producing manufactured goods. The manager of a large farm today has more in common with a General Motors factory superintendent than with a backyard gardener. Instead of steel, rubber, and fabric, the farm's inputs are sunlight, nutrients, chemicals, water, and germplasm; its factory is the soil, and nature does much of its labor. But the process is strikingly analogous. And just as the automakers have increased productivity by investing in new factories and new materials, so has agriculture increased yields by tinkering with its inputs. At first, farmers saved seeds from their best plants and set them aside for the next year's crop. Later, plant breeders began crossing strains with desirable traits to produce superplants, like the dwarf wheat and rice of the Green Revolution. Now, scientists are using the polymerase chain reaction and other genetic engineering tools to tinker with the DNA of plant cells and produce still stronger and more fruitful crops. Chemical fertilizers supplanted manures after World War II; now, high-tech organic farmers are nourishing their soil by planting leguminous cover crops in their orchards and vineyards and planning complex field crop rotations that include nitrogen fixers. Water management made its first great leap forward when the British diverted the Indus rivers. Then, during the 20th century, it made another with the construction of storage reservoirs, and still another with the introduction of plastic siphon tubes and laser-guided land levelling, devices far more advanced than any Sumerian could have imagined.

Now, we are on the cusp of another such leap. Drip irrigation, or something like it that allows farmers to micromanage their crops' water and nutrient rations, has the potential to extend the technological revolution that the British engineers began a century and a half ago, just as genetic engineering has the potential to continue what Gregor Mendel began with his pea plants in the monastery. When the British 
diverted the Indus rivers they transformed the ancient Sumerian art and gave the world the ability to feed its teeming populations of the 20th century, but the transformation was left unfinished. In the Indus, where illiterate peasants today struggle with one of the world's most technologically complex irrigation networks, the introduction of Green Revolution wheat seeds by itself boosted yields by $60 \%$ in 2 years in the late 1960s (Brown, 1970). But yields there and in other developing nations from Mexico to Morocco still fall short of what they could be, mainly because farmers lack the training, money, support, and equipment necessary to manage their fields to the demanding standards of the last decade of the 20th century. Meanwhile in advanced nations like the United States, even well-educated farmers cling to outmoded methods because they won't accept the financial risk that accompanies change. Worldwide, a 1982 study by the United Nations Food and Agriculture Organization estimated that there is enough farmland, sunshine and water on the planet to support, not 5 billion or 10 billion, but 30 billion people-but only if all of that land is managed to maximize yields with technologies that are now in use, such as drip irrigation (Norse, 1992). A world with 30 billion people may be frightening to contemplate. But a world with 10 billion is probably a certainty within the lifetimes of today's children. Highly efficient irrigation systems, and the concomitant increases in the efficiency with which nutrients are delivered to plants, may be all that will permit agriculture to make a graceful transition into the 21 st century, when it will have to feed twice as many people as today.

Based on the evidence to date, it is not at all certain that the transition will be made. Modern irrigation's environmental side effects - side effects that would be greatly lessened with more efficient water management - are creating problems all over the world in places like the Kesterson National Wildlife Refuge, the Tulare basin, the Colorado River delta, the Aral Sea, the Riverine Plain, and the valleys of the Nile, Indus, and Tigris-Euphrates. In some places, as in Pakistan, the damage is already severe; in others, such as the San Joaquin Valley of California, the reckoning may be still a few decades away. But there is not much time. An expert study completed in 1990 predicted that nearly 200,000 ha of the San Joaquin Valley's irrigated farmland may go out of production because of drainage problems by 2040, at a cost of 9000 jobs and \$441 million per year in crops (United States Department of the Interior, 1990). Plans for a salt disposal system for the valley - a concrete-lined drainage ditch that would empty into the Sacramento-San Joaquin River Delta above San Francisco Bayproved as early as the mid-1960s to be politically futile, strongly suggesting that the San Joaquin and other irrigated regions will henceforth be unable to simply export their salts to downstream neighbors. Meanwhile, production on much irrigated land worldwide is stagnant or declining. Even aside from loss of production, as world populations continue to double and redouble they may soon begin to outstrip the gains won by decades of improved plant breeding, nutrients, and irrigation. No one knows for certain when the two curves of population and food production will meet, or where the first effects will be felt. All that can be safely said is that, on the cusp of its third millennium, whether this civilization of ours will continue to prosper, or will collapse like its predecessors, is still uncertain.

The climate of the valley of the Tigris and Euphrates rivers, the socalled Fertile Crescent that cradled ancient Mesopotamia, has changed little over the millennia. It is a desert today, and it was a desert even at the dawn of Sumerian civilization 4200 years before Christ. At least 11 empires have risen and fallen in that arid valley, but today, modern Iraqis are able to produce only a little salt-tolerant barley there, even after spending vast sums of money to reclaim the salt-poisoned soil. Five thousand years ago, in contrast, the ancient Sumerians grew bountiful crops of wheat on those same lands. Their surpluses enabled them to expand their city states from their bases in the southern end of the valley; they built fortifications, raised armies, and attacked their neighbors, just as modern civilizations are prone to do. They prospered for at least 1000 years, and then they perished. Today, the southern Mesopotamian plain is a lightly populated and impoverished region, insignificant in comparison with the more prosperous central and northern parts of Iraq.
What happened? What could explain the slow but calamitous decline of the world's most highly developed civilization-a society that achieved literacy three millennia before Christ and still couldn't sustain itself? Some clues were provided by a group of anthropologists from the Oriental Institute at the Univ. of Chicago (Jacobsen, 1982; Weiss et al., 1993). These scientists deciphered cuneiform and other records and found evidence of an ancient dispute over water that turned disastrous. Two Sumerian city-states shared a watercourse that struck out from the Euphrates into the desert. About 2400 B.C., the upstream city, Umma, decided to cut off some of the flow to its downstream neighbor and keep more of the water for itself. The downstream city, Girsu, responded by building a new canal that went in the opposite direction and linked up with the Tigris. The new canal was safe from Umma's larceny, and with its water supply secure, Girsu continued to thrive. Over the succeeding years, it gradually enlarged the Tigris canal. New lands were irrigated, and more and more water was made available to the surrounding plains. But with so much water at their disposal, Girsu's farmers became profligate in its use. They overirrigated, and with nowhere else to go, the excess water merely seeped down to the water table. Slowly, the water table rose. The groundwater, which may have been only slightly salty at the time, was wicked up toward the surface as if the soil was a sponge. When it reached the surface, the water evaporated; the salt stayed behind. It took several centuries, but eventually so much salt built up in the soil that wheat would no longer germinate.

The anthropologists counted the impressions left in pieces of carbon-dated pottery by the different types of grain, and found that wheat had been almost completely replaced by more salt-tolerant barley in the lower Mesopotamian plain by 1700 B.C. Two thousand years earlier, the region's production had been equally divided between the two grains. And that was only the beginning. Eventually, the soil grew so salty that even barley refused to germinate. When that happened, ancient Sumeria went into eclipse, and the locus of Mesopotamian civilization quickly shifted upstream, toward what became Babylon. What had started as a great civilization based on a successful irrigation system ultimately was transformed, by virtue of over-irrigation and resultant salt accumulation, into a poisoned wasteland that barely rates a mention on today's maps of the world.

It took more than 3000 years for the ancient Sumerian civilization to be born, to grow, to flourish, to build its canals and irrigate its crops, and to slowly die. Its longevity exceeds that of any other civilization to this day. In contrast, what we have built in the world's arid regions in modern times is still in its infancy. Only 150 years have passed since the British overran the valley of the Indus, less than a century since the Bureau of Reclamation was founded, and not even five decades since the Central Valley Project was built. Without a sustained effort to head off the disastrous side-effects of those projects, our fate may be the same as ancient Sumeria's, and future archeologists may be left to puzzle over what became of us as well.

\section{Literature Cited}

Brown, L.R. 1970. Seeds of change: The Green Revolution and development in the 1960s. Praeger, New York

Brown, L.R. 1994. Facing food insecurity, p. 177-179. In: L.R. Brown (ed.). State of the world 1994. W.W. Norton, New York.

Horiuchi, S. 1992. Stagnation in the decline of the world population growth rate during the 1980s. Science 257:761-765.

Jacobsen, T. 1982. Salinity and irrigation agriculture in antiquity: Diyala Basin archeological projects, report on essential results, 1957-58. Undena Publ., Malibu, Calif.

Michel, A.A. 1969. The Indus Rivers. Yale Univ. Press, New Haven, Conn.

Norse, D. 1992. A new strategy for feeding a crowded planet. Environment 34:6-11.

U.S. Department of the Interior. 1990. Management plan for agricultural subsurface drainage and related problems on the westside San Joaquin Valley: Final report of the San Joaquin Valley Drainage Program. U.S. Dept. of the Interior, Sacramento, Calif.

Weiss, H., M.-A. Courty, W. Wetterstrom, F. Guichard, L. Senior, R. Meadow, and A. Curnow. 1993. The genesis and collapse of third millennium North Mesopotamian civilization. Science 26:995-1004. 